\title{
IgE to $\alpha$-Gal in Foresters and Forest Workers From La Rioja, North of Spain
}

\author{
Venturini $\mathrm{M}^{1}$, Lobera $\mathrm{T}^{1}$, Sebastián $\mathrm{A}^{2}$, Portillo $\mathrm{A}^{3}$, Oteo $\mathrm{JA}^{3}$ \\ ${ }^{1}$ Allergy Department, Hospital Universitario San Pedro, Logroño (La Rioja), Spain \\ ${ }^{2}$ Pneumology Department, Hospital Clínico Universitario Lozano Blesa, Zaragoza, Spain \\ ${ }^{3}$ Center of Rickettsioses and Arthropod-Borne Diseases, Hospital Universitario San Pedro-CIBIR, Logroño (La Rioja), Spain
}

J Investig Allergol Clin Immunol 2018; Vol. 28(2): 106-112

doi: 10.18176/jiaci.0218

\begin{abstract}
Objective: To investigate the prevalence of and factors associated with the presence of $\alpha$-gal-specific lgE in a risk group of foresters and forest workers from La Rioja, Spain and in a control group.

Methods: The study population comprised 169 workers and 100 individuals who did not recall having had tick bites. A questionnaire including demographic data and number of tick bites per year was completed by a physician. $\alpha$-Gal slgE was assessed using ImmunoCAP with serum samples that had been taken in 2010. In 2015, second serum specimens were taken from all but 1 of the workers, who had positive specific lgE to $\alpha$-gal in 2010. These new samples were tested for lgE to the $\alpha$-gal epitope and to mammalian meat.

Results: The prevalence of positive slgE to $\alpha$-gal was $15 \%$ in the risk population and $4 \%$ in the control population. $\alpha$-Gal slgE positivity was associated with the number of tick bites per year and with seniority. Thirteen out of 21 patients sensitized to $\alpha$-gal in 2010 showed positive specific lgE to $\alpha$-gal in serum samples from 2015. Eleven had specific lgE to mammalian meat, but none reported symptoms of meat allergy.

Conclusion: The prevalence of $\alpha$-gal slgE antibodies in this risk population was higher than in the control group and was associated with the number of tick bites per year and with seniority. None of the workers sensitized to mammalian meat developed meat allergy, possibly owing to the low levels of slgE to $\alpha$-gal.
\end{abstract}

Key words: Allergens and epitopes. IgE. Anaphylaxis. Tick bites. $\alpha$-Gal.

\section{Resumen}

Objetivo: Estudiar la prevalencia de IgE específica a $\alpha$-gal y los factores asociados en el grupo de riesgo de agentes forestales y retenes de incendios de La Rioja respecto a un grupo control.

Métodos: Se incluyeron 169 trabajadores y 100 personas que referían no haber sufrido picaduras de garrapata. Cumplimentaron un cuestionario dirigido en el que se recogieron datos demográficos y número de picaduras de garrapata al año. Se realizó determinación de IgE específica a $\alpha$-gal mediante la ténica InmunoCAP utilizando muestras serológicas extraídas en 2010. En 2015 se llevó a cabo nueva extracción serológica a todos los trabajadores sensibilizados a $\alpha$-gal en muestra de 2010 excepto a uno. Se realizó nueva determinación de lgE específica a $\alpha$-gal y a carne de mamíferos.

Resultados: La prevalencia de IgE específica a $\alpha$-gal en la población de riesgo fue del $15 \%$ vs. 4\% en el grupo control. La positividad de la lgE específica a $\alpha$-gal se asoció con el número de picaduras al año y con la antigüedad el puesto de trabajo. Trece de los pacientes sensibilizados en 2010 seguían sensibilizados en 2015. Once de ellos mostraban IgE específica frente a carnes sin manifestar síntomas de alergia.

Conclusión: La prevalencia de IgE específica a $\alpha$-gal en población de riesgo española fue superior a la del grupo control y se asoció al número de picaduras-año y a la antigüedad en el puesto de trabajo. Ninguno de los trabajadores sensibilizados a carnes, desarrolló alergia, probablemente por los niveles discretos de IgE específica a $\alpha$-gal.

Palabras clave: Alérgenos y epítopos. IgE. Anafilaxia. Picaduras de garrapata. $\alpha$-Gal. 


\section{Introduction}

Antibodies to $\alpha$-gal are present in all nonimmunocompromised individuals, with early studies suggesting that the IgG antibodies to $\alpha$-gal constituted about $1 \%$ of circulating immunoglobulins in humans, apes, and Old World monkeys [1]. These antibodies are produced continuously throughout life as an immune response to antigenic stimulation by bacteria of normal flora. However, $\operatorname{IgE}$ antibodies to $\alpha$-gal are produced in a variable percentage of the population depending on the geographical area [2-9]. They are the cause of various forms of anaphylaxis: delayed-onset anaphylaxis 3 to 6 hours after ingestion of red meat [3,7,10-20] and immediate-onset anaphylaxis after exposure to the monoclonal antibody cetuximab [2], Crotalidae polyvalent immune Fab antivenom [21], zoster vaccine [22], vaginal capsules [23], bovine-derived gelatine colloids [13], bioprosthetic aortic valve [24], bovine amniotic fluid [25], and gelatin-containing sweets [26].

To date, tick bites are the only proven cause of $\operatorname{IgE}$ to $\alpha$-gal [27]. This association was first detected in the USA by Commins et al [4], who reported a strong correlation between $\operatorname{IgE}$ to $\alpha$-gal and history of tick bites and found that these antibodies were not produced in regions where tick bites were not common. The same authors also reported the correlation between IgE antibodies to proteins derived from Amblyomma americanum ticks and $\operatorname{IgE}$ to $\alpha$-gal. Several studies later showed an association between $\operatorname{IgE}$ to $\alpha$-gal and tick bites of Ixodes holocyclus in Australia [10] or Ixodes ricinus in Europe [7,8]. Lastly, Hamsten et al [28] demonstrated that the $\alpha$-gal epitope was present in the gastrointestinal tract of I ricinus using immunohistochemistry.

La Rioja is an area in the north of Spain with a very rich flora and fauna and that constitutes an ideal habitat for ticks. In this region, the ticks that most frequently parasitize humans belong to the genera Ixodes, Rhipicephalus, and Dermacentor [29].

We performed this study to investigate the prevalence of and factors associated with the presence of $\alpha$-gal-specific IgE in a risk group of foresters and forest workers from La Rioja and in people with no knowledge of having been bitten by ticks (control group).

We also studied changes in the level of specific IgE to $\alpha$-gal in sensitized patients after 5 years to investigate the relationship with the number of bites experienced during the interim period.

\section{Methods}

\section{Patients}

The initial study population comprised all 169 persons on the list of foresters, forest workers, and drivers provided by the Consejeria de Medio Ambiente del Gobierno de La Rioja in 2010 (equivalent to the Environment Ministry). All 169 individuals were highly likely to have experienced multiple tick bites. The control group comprised individuals who attended the Allergy Unit at Hospital San Pedro, Logroño, Spain for allergy to ß-lactam antibiotics from February to April 2015 and reported that they had never been bitten by ticks.

\section{Ethical Issues}

All individuals consented to participate in the study, which was approved by the Institutional Review Boards (Ethics Committee, La Rioja, Spain, code PI-175) and conformed to the current Declaration of Helsinki.

\section{Questionnaires}

A structured questionnaire including basic demographic data (age, gender, seniority, and geographical working area) was administered in 2015 by a physician. Three geographical areas were established (High Rioja, Mid Rioja and Low Rioja), and participants were grouped according to their area of work (in the valley or in the mountains) in order to obtain potentially interesting data on the distribution of ticks.

Clinical data obtained from patients included information about atopy, history of tick bites, number of bites/year, and localized or generalized allergic reactions to tick bites. In order to determine the tick species causing the bites, we asked about the month of the year when tick bites occurred and the area of the body affected. We also asked about food allergies (specifically, red meat allergy) and present or past cancer requiring treatment with cetuximab.

Finally, we asked if the number of tick bites/year during the previous 5 years had been greater than, the same as, or lower than before 2010 .

\section{Serum slgE to the $\alpha$-Gal Epitope and to Beef, Pork, and Chicken}

Serum samples from the foresters and forest workers and from the control group were tested in 2015 for $\operatorname{IgE}$ to $\alpha$-gal (o215) using the ImmunoCAP 250 automated platform (Thermo Fisher Scientific). Serum samples from 2010 stored in the serum bank of the Department of Infectious Diseases at Hospital San Pedro-Center of Biomedical Research of La Rioja (CIBIR) were used to analyze the professional risk group; the remaining serum samples from the drug allergy study carried out in 2015 were used for the control group. All but 1 of the foresters and forest workers with positive specific $\operatorname{IgE}$ to $\alpha$-gal were tested again for IgE to the $\alpha$-gal epitope, to beef meat (f27), pork meat (f26), and chicken meat (f83) using serum samples taken in 2015. The cut-off values for IgE were $\geq 0.1 \mathrm{kU} / \mathrm{L}$, as suggested by the manufacturer.

\section{Statistical Analysis}

The statistical analysis was performed using SPSS software, version 21.

Normally distributed variables were expressed as mean (SD); nonnormally distributed variables were expressed as median (IQR).

A 2-sided $P$ value of less than .05 was considered to indicate statistical significance. The chi-square test was used to investigate associations between categorical variables. The $t$ test and the Wilcoxon test (when appropriate) were used to compare numerical variables between the groups. We compared quantitative continuous variables by using the Spearman rank correlation coefficient. Logistic regression was used for multivariate analysis of factors associated with positivity to $\alpha$-gal IgE. 


\section{Results}

A total of 147 of 169 at-risk workers agreed to participate in the study (65/71 forest officials [91.5\%], 75/91 forest workers [82.4\%], and $7 / 7$ drivers [100\%]). The questionnaire and the serum specific IgE test for the $\alpha$-gal epitope were administered in all 147 participants (mean age, 40.5 years; 145 men and 2 women) with serum samples from 2010. A total of 100 serum samples were also analyzed as controls.

The prevalence of $\alpha$-gal sIgE in the study population was $15 \%(22 / 147)$, which proved to be significantly higher than the prevalence in the control population $(4 \% ; 4 / 100)(\mathrm{OR}, 4.2$; $95 \% \mathrm{CI}, 1.4-12.6)$. Individual data for cases with $\alpha$-gal $\operatorname{sigE}$ $\geq 0.1 \mathrm{kU}_{\mathrm{A}} / \mathrm{L}$ are shown in Table 1 . Titers were generally low. In the professional group, the median was $0.22(0.19) \mathrm{kU}_{\mathrm{A}} / \mathrm{L}$. The control group had lower titers (minimum 0.1 and maximum $0.15 \mathrm{kU}_{\mathrm{A}} / \mathrm{L}$ ). Only 5 individuals from the foresters and forest workers $(3.4 \%)$ and none from the control group $(0 \%)$ had $\alpha$-gal sIgE levels $\geq 0.35 \mathrm{kU}_{\mathrm{A}} / \mathrm{L}$ (the classic threshold for positivity), and only 1 forester had a level $\geq 3.5 \mathrm{kU}_{\mathrm{A}} / \mathrm{L}$ (class 3 or higher).

A total of 124 individuals $(84.4 \%)$ reported a history of tick bites, while $23(15.6 \%)$ were not aware of having experienced tick bites. A statistically significant difference was found between the number of bites per year and sensitization to $\alpha$-gal (Spearman rank correlation coefficient, $0.22 ; P<.008)$. The percentages of $\alpha$-gal-sensitized persons in the professional group were as follows: $4 \%$ for workers who were unaware of having experienced tick bites, $12 \%$ for those who had experienced $0-5$ bites per year, $13 \%$ for those who had experienced 5-10 bites per year, 28\% for those who had experienced 10-20 bites per year, and 33\% for those who had experienced more than 20 tick bites per year.

The mean age was $39.89(8.99)$ years in the nonsensitized workers and 43.95 (8.92) years in the sensitized workers $(P=.052)$. The mean number of years in the workplace was $16.95(8.96)$ for the sensitized patients and 12.92 (8.38) for the nonsensitized workers. These differences were statistically significant $(P=.041)$. Logistic regression analysis revealed seniority and number of tick bites to be associated with an increased risk of sensitization to $\alpha$-gal, regardless of the other variables analyzed. Thus, workers with more than 10 tick bites per year had a statistically significant risk of sensitization to $\alpha$-gal compared with workers who had not experienced bites. The association between age and sensitization to $\alpha$-gal was

Table 1. Specific lgE to $\alpha$-Gal and Meats $\left(\mathrm{kU}_{\mathrm{A}} / \mathrm{L}\right)$ in the 22 Sensitized Professionals

\begin{tabular}{|c|c|c|c|c|c|}
\hline Patient & $\begin{array}{c}\text { ImmunoCAP } \\
\alpha-G a l(2010), \mathrm{kU}_{\mathrm{A}} / \mathrm{L}\end{array}$ & $\begin{array}{c}\text { ImmunoCAP } \\
\alpha-\mathrm{Gal}(2015), \mathrm{kU}_{\mathrm{A}} / \mathrm{L}\end{array}$ & $\begin{array}{c}\text { ImmunoCAP } \\
\text { Pork (2015), } \mathrm{kU}_{\mathrm{A}} / \mathrm{L}\end{array}$ & $\begin{array}{c}\text { ImmunoCAP } \\
\text { Beef (2015), } \mathrm{kU}_{\mathrm{A}} / \mathrm{L}\end{array}$ & $\begin{array}{c}\text { ImmunoCAP } \\
\text { Chicken (2015), } \mathrm{kU}_{\mathrm{A}} / \mathrm{L}\end{array}$ \\
\hline 1 & 0.10 & 0.09 & 0.05 & 0.06 & 0.01 \\
\hline 2 & 0.95 & 0.71 & 0.11 & 0.31 & 0.02 \\
\hline 3 & 0.19 & 0.10 & 0.04 & 0.11 & 0.15 \\
\hline 4 & 0.54 & 5.48 & 1.29 & 1.29 & 0.03 \\
\hline 5 & 0.72 & 0.66 & 0.23 & 0.29 & 0.02 \\
\hline 6 & 0.14 & 0.02 & 0.03 & 0.03 & 0.02 \\
\hline 7 & 18.20 & 6.19 & 1.54 & 2.31 & 0.03 \\
\hline 8 & 0.39 & 0.09 & 1.39 & 0.52 & 0.04 \\
\hline 9 & 0.21 & 0.64 & 0.38 & 0.36 & 0.05 \\
\hline 10 & 0.25 & 0.23 & 0.04 & 0.05 & 0.06 \\
\hline 11 & 0.32 & 0.04 & 0.04 & 0.06 & 0.01 \\
\hline 12 & 0.32 & 0.05 & 0.06 & 0.06 & 0.06 \\
\hline 13 & 0.29 & 0.40 & 0.00 & 0.43 & 0.28 \\
\hline 14 & 0.10 & 0.46 & 0.08 & 0.15 & 0.01 \\
\hline 15 & 0.14 & 0.01 & 0.02 & 0.04 & 0.01 \\
\hline 16 & 0.19 & 0.04 & 0.02 & 0.03 & 0.02 \\
\hline 17 & 0.10 & 0.28 & 0.08 & 0.12 & 0.05 \\
\hline 18 & 0.25 & 1.21 & 0.07 & 0.17 & 0.03 \\
\hline 19 & 0.14 & 0.04 & 0.02 & 0.03 & 0.02 \\
\hline 20 & 0.15 & 0.80 & 0.06 & 0.09 & 0.02 \\
\hline 21 & 0.23 & 0.11 & 0.07 & 0.09 & 0.03 \\
\hline 22 & 0.11 & NP & NP & NP & NP \\
\hline
\end{tabular}

Abbreviation: NP, not performed. 
Table 2. Logistic Regression Model: Sensitization to $\alpha$-Gal With Respect to Age, Seniority, and Number of Bites Per Year

\begin{tabular}{lccc}
\hline & Coef & OR & $\begin{array}{c}\text { Confidence } \\
\text { Interval }\end{array}$ \\
\hline Seniority & 0.068 & 1.07 & 1.01 to 1.13 \\
\hline $\begin{array}{l}\text { Bites per year } \\
\text { From <5 bites vs } 0 \text { bites }\end{array}$ & 1.26 & 3.54 & 0.40 to 30.8 \\
$\begin{array}{l}\text { Between } 5 \text { and } 10 \text { bites } \\
\text { vs } 0 \text { bites }\end{array}$ & 1.61 & 5.03 & 0.49 to 51.4 \\
Eleven to 20 bites vs 0 bites & 2.37 & 10.71 & 1.01 to 113.13 \\
Over 20 bites vs 0 bites & 2.76 & 15.89 & 1.51 to 166.95 \\
\hline Age & 0.017 & 1.01 & 0.92 to 1.11 \\
\hline
\end{tabular}

lost when other variables (number of tick bites and seniority in the workplace) were considered as confounders (Table 2).

In Spain, tick bites occurring during winter or affecting the scalp are probably caused by ticks of the genus Dermacentor. No significant differences were found between sensitization to $\alpha$-gal and data suggesting bites by Dermacentor species, atopy, local reaction to tick bites, and geographical working areas of foresters and forest workers (Table 3 ).

Twenty-one of the 22 patients sensitized to $\alpha$-gal in serum samples from 2010 were tested again for $\operatorname{IgE}$ to the $\alpha$-gal

Table 3. Relationship Between $\alpha-G a l$ lgE Response and the Variables Atopy, Local Reaction to Tick Bites, Geographical Working Area of Foresters and Forest Workers, and Data Suggesting Bites by Dermacentor Species

\begin{tabular}{|c|c|c|c|}
\hline \multirow[t]{2}{*}{ Variable } & \multicolumn{2}{|c|}{$\alpha$-Gal-IgE Response } & \multirow{2}{*}{$\begin{array}{c}P \\
\text { Value }\end{array}$} \\
\hline & No & Yes & \\
\hline \multicolumn{4}{|l|}{ Atopy } \\
\hline No & $93 / 110(84.5 \%)$ & $17 / 110(15.5 \%)$ & .8 \\
\hline Yes & $32 / 37(86.5 \%)$ & $5 / 37(13.5 \%)$ & \\
\hline \multicolumn{4}{|l|}{ Local reaction } \\
\hline No & $76 / 87(87.4 \%)$ & $11 / 87(12.6 \%)$ & .34 \\
\hline Yes & $49 / 60(81.7 \%)$ & $11 / 60(18.3 \%)$ & \\
\hline \multicolumn{4}{|l|}{ Geographical area } \\
\hline High Rioja & $53 / 61(86.9 \%)$ & $8 / 61(13.1 \%)$ & .44 \\
\hline Mid Rioja & $43 / 54(79 \%)$ & $11 / 54(20.4 \%)$ & \\
\hline Low Rioja & $23 / 26(88.5 \%)$ & $3 / 26(11.5 \%)$ & \\
\hline All over Rioja & $6 / 6(100 \%)$ & $0 / 6(0 \%)$ & \\
\hline Mountains & $96 / 116(82.8 \%)$ & $20 / 116(17.2 \%)$ & .28 \\
\hline Valley & $23 / 25(92 \%)$ & $2 / 25(8 \%)$ & \\
\hline Mountains and valley & y $6 / 6(100 \%)$ & $0 / 6(0 \%)$ & \\
\hline \multicolumn{4}{|l|}{$\begin{array}{l}\text { Data suggesting bites } \\
\text { by Dermacentor species }\end{array}$} \\
\hline \multicolumn{4}{|l|}{ Bites during Winter } \\
\hline No & $99 / 120(82.5 \%)$ & $21 / 120(17.5 \%)$ & .18 \\
\hline Yes & $4 / 4(100 \%)$ & $0 / 4(0 \%)$ & \\
\hline \multicolumn{4}{|l|}{ Bites affecting the head } \\
\hline No & $87 / 105(82.9 \%)$ & $18 / 105(17.2 \%)$ & \\
\hline Yes & $16 / 19(84.2 \%)$ & $3 / 19(15.8 \%)$ & .29 \\
\hline
\end{tabular}

epitope with sera taken in 2015 (Table 1). In this determination, 13 patients still had specific IgE to $\alpha$-gal $>0.1 \mathrm{kU}_{\mathrm{A}} / \mathrm{L}$, while in 8 patients, specific IgE to $\alpha$-gal had become negative. In these 13 patients, the median was $0.64(0.75) \mathrm{kU}_{\mathrm{A}} / \mathrm{L}$, and 9 had $\alpha$-gal sIgE levels $\geq 0.35 \mathrm{kU}_{\mathrm{A}} / \mathrm{L}$. The mean difference in specific IgE to $\alpha$-gal samples between 2010 and 2015 was $-0.31 \mathrm{kU}_{\mathrm{A}} / \mathrm{L}$, with a slight decrease in the $\mathrm{IgE}$ value in 2015 . These differences were not significant.

Comparison of changes in specific IgE with respect to having had a larger or smaller number of bites from 2010 to 2015 did not reveal differences, since all the patients but one reported the same number of bites per year before and after 2010. Fewer bites during the 5 -year interval were reported by only 1 patient, in whom IgE to $\alpha$-gal had become negative.

Six patients had specific $\mathrm{IgE}$ to pork $>0.1 \mathrm{kU}_{\mathrm{A}} / \mathrm{L}$ (median $0.84[1.23] \mathrm{kU}_{\mathrm{A}} / \mathrm{L}$ ) and 11 had specific $\operatorname{IgE}$ to beef (median $\left.0.31[0.37] \mathrm{kU}_{\mathrm{A}} / \mathrm{L}\right)$.

Therefore, the prevalence of sensitization to red meat in the sample of 13 patients sensitized to $\alpha$-gal with serum taken in 2015 was $77 \%$ (95\%CI, 55\%-99\%). A high correlation was detected between specific IgE values to $\alpha$-gal and specific IgE values to pork (Pearson correlation coefficient, $0.76[P<.01]$ ) and very high correlation with beef (Pearson correlation coefficient, $0.93[P<.01])$. Specific IgE values to chicken were found in 2 patients $\left(0.28\right.$ and $0.15 \mathrm{kU}_{\mathrm{A}} / \mathrm{L}$, respectively). No patients had clinical allergy to mammalian meat.

\section{Discussion}

The prevalence of sensitization to $\alpha$-gal in foresters and forest workers exposed to multiple tick bites in La Rioja was higher than in people who were not aware of having been bitten by ticks ( $15 \%$ vs $4 \%$ ), thus showing that tick bites are the only proven cause of IgE antibodies to $\alpha$-gal [27]. These results are not comparable to those found in our preliminary study carried out in La Rioja (29\% sensitization to $\alpha$-gal) [30]. The previous study population included people who reported multiple tick bites, whereas in the present study, $15 \%$ of forest workers reported that they had never had tick bites. However, our results were not consistent with those reported for the general population. Thus, reported values were $15 \%-20 \%$ in southeastern USA [2-5], 25\% in a rural area of southwestern Italy [9], 10\% in Stockholm (Sweden) [7], 8\% in northwestern Spain, and 5\% in Denmark [8]. Very high percentages in areas with tropical climates such as Kenya (76\%) and northwestern Ecuador (37\%) had also been reported [4]. Disparities can be attributed to different criteria for establishing the cut-off value of specific IgE to $\alpha$-gal. The cut-off value applied in the present study $\left(0.1 \mathrm{kU}_{\mathrm{A}} / \mathrm{L}\right)$ was that recommended by the manufacturer. Reports carried out in the USA considered a specific IgE value to $\alpha$-gal $>0.35 \mathrm{kU}_{\mathrm{A}} / \mathrm{L}$ as positive [2-5], whereas the same criterion as ours was used in Sweden [7], Denmark, Spain [8], and Italy [9]. In 2 of these studies, the prevalence of sensitization to $\alpha$-gal fell by half [9] and even decreased 4-fold [8] when the criterion of positivity was changed to $0.35 \mathrm{kU}_{\mathrm{A}} / \mathrm{L}$, since most sensitized cases showed specific IgE in this range $\left(0.1-0.35 \mathrm{kU}_{\mathrm{A}} / \mathrm{L}\right)$. In our study, when the positivity threshold was increased to $0.35 \mathrm{kU}_{\mathrm{A}} / \mathrm{L}$, the prevalence of sensitization decreased to $3.4 \%$ (only 5 workers showed 
specific $\operatorname{IgE}$ to $\alpha$-gal $>0.35 \mathrm{kU}_{\mathrm{A}} / \mathrm{L}$ in the sample from 2010 ). Nevertheless, 9 patients had specific $\operatorname{IgE}$ to $\alpha$-gal $>0.35 \mathrm{kU}_{\mathrm{A}} / \mathrm{L}$ in 2015, suggesting that the prevalence of sensitization would be higher, although we could not calculate this value because our determination was limited to patients sensitized in 2010 .

Since the prevalence of sensitization to $\alpha$-gal in the risk group was lower than that of the general population from southeast USA, we can deduce that the prevalence in the general population of La Rioja would be even lower than that of the general population in the southeast USA, because tick species parasitizing humans in our area (mainly Ixodes, Dermacentor, and Rhipicephalus) are not as aggressive as Amblyomma americanum, the predominant species in the USA, or perhaps because their ability to induce sensitization to $\alpha$-gal could be lower. Currently, the presence of $\alpha$-gal in the digestive tract of I ricinus nymphs has been detected by immunohistochemistry [28], but the origin of this carbohydrate determinant, which subsequently induces $\operatorname{IgE}$ production, is still unknown. Various theories hold that it is a component of saliva, it is part of a glycoprotein or glycolipid from the tick through the intake of blood in a previous feeding, or it is found in microorganisms such as Rickettsia or Borrelia that are present in ticks [27].

We demonstrated an association between a history of tick bites and sensitization to $\alpha$-gal. We also found a linear correlation between the number of tick bites/year and the probability of being sensitized to $\alpha$-gal. Logistic regression analysis showed that 10 bites per year was a risk factor for sensitization to $\alpha$-gal regardless of the number of years working and age, with respect to people who did not recall tick bites. In any case, the tick species that had bitten the patients in the present study were not determined, although we assumed that tick bites in winter were caused by Dermacentor species, since this species is active during cold months. Thus, our data, only allow us to state that there was no relationship between having experienced bites by Dermacentor species and sensitization to $\alpha$-gal. These findings are consistent with those of a study that found a correlation between specific IgE to $\alpha$-gal and bites by A americanum, but not for bites by Dermacentor variabilis [4].

Four people from the control group (4\%) were sensitized to $\alpha$-gal, with values ranging from $0.1 \mathrm{kU}_{\mathrm{A}} / \mathrm{L}$ to $0.15 \mathrm{kU}_{\mathrm{A}} / \mathrm{L}$, possibly because some tick bites went unnoticed. Only $50 \%$ $70 \%$ of patients diagnosed with Lyme disease recalled having been bitten by ticks [31,32]. Moreover, 1 out of 23 foresters and forest workers (4\%) who believed that they had never had tick bites was sensitized to $\alpha$-gal.

Also interesting is the association we found between sensitization to $\alpha$-gal and the variables seniority and age. This association was less intense with age and, logically, was lost in the logistic regression analysis, since age itself is not a risk factor if the patient is not at risk of bites.

Participants who worked in mountain areas and Mid Rioja (Cameros mountains) were twice as likely to be sensitized as workers from the valley and Low and High Rioja, although the differences were not significant. This finding supports the fact that ticks are more abundant in mountain areas with a supra-Mediterranean climate, which is suitable for livestock and forestry activities. In addition, I ricinus ticks are more frequent in mountain areas. This species bites humans more frequently than other species such as Haemaphysalis, which is more commonly found in the valley, where the climate is Meso-Mediterranean.

We found that $77 \%$ foresters and forest workers sensitized to $\alpha$-gal were also sensitized to mammalian meat, although none of them showed symptoms of meat allergy. This could be explained by the discrete values of specific $\operatorname{IgE}$ to $\alpha$-gal (in class 1 or 2 ) detected for all but 2 patients (whose values belonged to class 3 ). In our experience, and also according to findings of the other research groups, patients allergic to red meat typically showed very high levels of specific $\operatorname{IgE}$ to $\alpha$-gal, although sometimes they developed clinical symptoms with IgE values in class 1 or $2[2,7,12,14,17,33]$.

In conclusion, we found that the prevalence of $\alpha$-gal $\operatorname{sgE}$ in the risk population of foresters and forest workers was higher than in the control population. In addition, the prevalence of $\operatorname{sIgE}$ to $\alpha$-gal and the number of reported tick bites per year and seniority were related. We demonstrated that tick species parasitizing humans in the north of Spain are able to induce $\alpha$-gal sIgE. Many patients sensitized to $\alpha$-gal were also sensitized to mammalian meat. Since successive tick bites can induce increased sensitization to $\alpha$-gal and the development of meat allergy, we recommend that this risk group take precautionary measures to prevent further tick bites [34].

\section{Addendum}

While we were reviewing this paper, Fisher et al [35] reported the results of a cross-sectional study about prevalence of $\alpha$-gal-specific IgE in 300 forest service employees and hunters from southwest Germany.

\section{Acknowledgments}

The authors thank Dr Jacinta Gaviria for providing serum samples and Dr Enrique Ramalle for his help with the statistical analyses.

\section{Funding}

Thermo Fisher Scientific supported the study by performing the IgE determinations.

\section{Conflicts of Interest}

The authors declare that they have no conflicts of interest.

\section{Previous Presentation}

Some of the data in the present study were presented in an oral communication at the XXX Congreso Nacional de la Sociedad Española de Alergología e Inmunología Clínica.

\section{References}

1. Galili U. Anti-Gal: an abundant human natural antibody of multiple pathogeneses and clinical benefits. Immunology. 2013;140:1-11.

2. Chung CH, Mirakhur B, Chan E, Le QT, Berlin J, Morse M, et al. Cetuximab-induced anaphylaxis and IgE specific for galactose-alpha-1,3-galactose. N Engl J Med. 2008;358: 1109-17. 
3. Commins SP, Satinover SM, Hosen J, Mozena J, Borish L, Lewis $B D$, et al. Delayed anaphylaxis, angioedema, or urticaria after consumption of red meat in patients with IgE antibodies specific for galactose-alpha-1,3-galactose. J Allergy Clin Immunol. 2009:123:426-33.

4. Commins SP, James HR, Kelly LA, Pochan SL, Workman LJ, Perzanowski MS, et al. The relevance of tick bites to the production of $\mathrm{IgE}$ antibodies to the mammalian oligosaccharide galactose- $\alpha-1,3$-galactose. J Allergy Clin Immunol. 2011;127:1286-93.

5. Commins SP, Kelly LA, Rönmark E, James HR, Pochan SL, Peters EJ, et al. Galactose- $\alpha-1,3$ galactose-specific lgE is associated with anaphylaxis but not asthma. Am J Respir Crit Care Med. 2012;185:723-30.

6. Arkestal K, Sibanda E, Thors C, Troye-Blomberg M, Mduluza T, Valenta $R$, et al. Impaired allergy diagnostics among parasiteinfected patients caused by lgE antibodies to the carbohydrate epitope galactose- $\alpha$ 1,3-galactose. J Allergy Clin Immunol 2011;127:1024-8

7. Hamsten C, Tran TA, Starkhammar M, Brauner A, Commins S, Platts-Mills $T$, et al. Red meat allergy in Sweden: Association with tick sensitization and B negative blood groups. J Allergy Clin Immunol. 2013;132:1431-4.

8. Gonzalez-Quintela A, Dam Laursen AS, Vidal C, Skaaby T, Gude F, Linneberg A. IgE antibodies to alpha-gal in the general adult population: relationship with tick bites, atopy, and cat ownership. Clin Exp Allergy. 2014;44:1061-8.

9. Villalta D, Pantarotto L, Da Re M, Conte M, Sjolander S, Borres MP, et al. High prevalence of slgE to Galactose- $\alpha-1,3-$ galactose in rural pre-Alps area: a cross-sectional study. Clin Exp Allergy. 2016;46:377-80.

10. Van Nunen SA, O'Connor KS, Clarke LR, Boyle RX, Fernando $\mathrm{SL}$. An association between tick bite reactions and red meat allergy in humans. Med J Aust. 2009;190:510-1.

11. Jacquenet S, Moneret-Vautrin D, Bihain BE. Mammalian meat-induced anaphylaxis: Clinical relevance of antigalactose- $\alpha-1,3$-galactose IgE confirmed by means of skin tests to cetuximab. J Allergy Clin Immunol. 2009;124:603-5.

12. Nuñez R, Carballada F, Gonzalez-Quintela A, Gomez-Rial $J$, Boquete M, Vidal C. Delayed mammalian meat-induced anaphylaxis due to galactose-alpha-1,3-galactose in 5 European patients. J Allergy Clin Immunol. 2011;128:11224.

13. Mullins RJ, James $H$, Platts-Mills TAE, Commins $S$. The relationship between red meat allergy and sensitization to gelatin and galactose-alpha-1,3-galactose. J Allergy Clin Immunol. 2012;129:1334-42.

14. Morisset M, Richard C, Astier C, Jacquenet S, Croizier A, Beaudouin $E$, et al. Anaphylaxis to pork kidney is related to lgE antibodies specific for galactose-alpha-1,3-galactose. Allergy. 2012;67:699-704.

15. Kennedy $J$, Stallings AP, Platts-Mills TA, Oliveira WM, Workman L, James HR, et al. Galactose- $\alpha$-1,3-galactose and delayed anaphylaxis, angioedema and urticaria in children. Pediatrics. 2013;131:1545-52.

16. Wolver SE, Sun DR, Commins SP, Schwartz LB. A peculiar cause of anaphylaxis: no more steak? The journey to discovery of a newly recognized allergy to galactose-alpha-1,3-galactose found in mammalian meat. J Gen Intern Med. 2013;28:322-5.
17. Carrapatoso I, Bartolomé B, Ribeiro F, Martínez J, Segorbe A. Allergy to red meat in adulthood: a case report. J Invest Allergol Immunol. 2014;24:192-211.

18. Fischer J, Hebsaker J, Caponetto P, Platts-Mills T, Biedermann T. Galactose alpha-1,3-galactose sensitization is a prerequisite for pork-kidney allergy and cofactor related mammalian meat anaphylaxis. J Allergy Clin Immunol. 2014;134:755-9.

19. Michel S, Scherer K, Heijnen IAFM, Bircher AJ. Skin prick test and basophil reactivity to cetuximab in patients with $\lg E$ to alpha-gal and allergy to red meat. Allergy 2014; 69: 403-5.

20. Wen L, Zhou J, Sun JL, Wu K, Katial R. Delayed anaphylaxis to red meat associated with specific lgE antibodies to galactose. Allergy Asthma Immunol Res. 2015;7:92-4.

21. Rizer J, Brill K, Charlton N, King J. Acute hypersensitivity reaction to Crotalidae polyvalent immune Fab (CroFab) as initial presentation of galactose- $\alpha-1,3$-galactose ( $\alpha$-gal) allergy. Clin Toxicol. 2017;55:668-9.

22. Stone CA, Hemler JA, Commins SP, Schuyler AJ, Phillips EJ, Peebles RS, et al. Anaphylaxis after zoster vaccine: Implicating alpha-gal allergy as a possible mechanism. J Allergy Clin Immunol. 2017;139:1710-3.

23. Vidal C, Méndez-Brea P, López-Freire S, González-Vidal T. Vaginal Capsules: An Unsuspected Probable Source of Exposure to $\alpha$-Gal. J Investig Allergol Clin Immunol. 2016;26:388-9.

24. Mozzicato SM, Tripathi A, Posthumus JB, Platts-Mills TAE, Commins SP. Porcine or bovine valve replacement in 3 patients with $\lg \mathrm{E}$ antibodies to the mammalian oligosaccharide galactose-alpha-1,3-galactose. J Allergy Clin Immunol Pract. 2014;2:637-8.

25. Nuñez-Orjales R, Martin-Lazaro J, Lopez-Freire S, Galan-Nieto A, Lombardero-Vega M, Carballada-Gonzalez F. Bovine Amniotic Fluid: A New and Occupational Source of Galactose- $\alpha-1,3-$ Galactose. J Investig Allergol Clin Immunol. 2017;27:313-4.

26. Caponetto P, Fischer J, Biedermann T. Gelatin-containing sweets can elicit anaphylaxis in a patient with sensitization to galactose- $\alpha-1,3$-galactose. J Allergy Clin Immunol Pract. 2013;1:302-3.

27. Steinke JW, Platts-Mills TA, Commins SP. The alpha-gal story: Lessons learned from connecting the dots. J Allergy Clin Immunol. 2015;135:589-96.

28. Hamsten C, Starkhammar $M$, Tran TA, Johansson $M$, Bengtsson $U$, Ahlén $G$, et al. Identification of galactose- $\alpha$ 1,3-galactose in the gastrointestinal tract of the tick Ixodes ricinus; possible relationship with red meat allergy. Allergy. 2013;68:549-52.

29. Palomar AM, Portillo A, Eiros JM, Oteo JA. The risk of introducing tick-borne encephalitis and Crimean-Congo hemorrhagic fever into southwestern Europe (Iberian peninsula). Virology II - Advanced Issues, iConcept Press Ltd (2013). Retrieved from https://www.iconceptpress.com/book/ virology-ii-advanced-issues/11000086/.

30. Venturini M, Lobera T, Portillo A, Oteo JA, Blasco A, González I. Sensibilización a alfa-gal en pacientes con múltiples picaduras de garrapata en La Rioja. J Invest Allergol Clin Immunol. 2013;23 Supplement 2:165-203.

31. Maurer FP, Keller PM, Beuret C, Joha C, Achermann Y, Gubler J, et al. Close geographic association of human neoehrlichiosis 
and tick populations carrying "Candidatus Neoehrlichia mikurensis" in eastern Switzerland. J Clin Microbiol. 2013;51:169-76.

32. Grankvist A, Andersson PO, Mattsson M, Sender M, Vaht $K$, Höper $L$, et al. Infections with the tick-borne bacterium "Candidatus Neoehrlichia mikurensis" mimic noninfectious conditions in patients with B cell malignancies or autoinmune diseases. Clin Infect Dis. 2014;58:1716-22.

33. Martínez A, Audícana MT, Longo N, Fernández E, Villarreal 0 , Velasco M, et al. Allergy to Galactose-Alpha-1,3-Galactose: Clinical Features and the Diagnostic Value of Cetuximab. J Investig Allergol Clin Immunol. 2014;24:450-2.

34. Garcia-Alvarez L, Palomar AM, Oteo JA. Prevention and prophylaxis of tick bites and tick-borne related diseases. Am J Infect Dis. 2013;9:104-16.

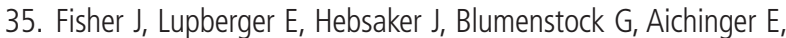
Yazdi AS, et al. Prevalence of type I sensitization to alpha-gal in forest service employees and hunters. Allergy. 2017;72:1540-7.

- Manuscript received August 17, 2017; accepted for publication December 1, 2017.

\section{Mónica Venturini Díaz}

Unidad de Alergología, CARPA-San Millán

C/ Obispo Lepe $\mathrm{s} / \mathrm{n}$

26004 Logroño (La Rioja), Spain

E-mail: mventurini@riojasalud.com 